\title{
Western Arctic Women Artists: An Ethnographic Study of the Historic Influences on the Artistic Education and Production of Women from Three Co-existing cultures
}

\section{Joanne McNeal}

\begin{abstract}
Indigenous women in the Western Arctic have produced artwork for hundreds of years as their contribution to their family's survival. With the arrival of the European explorers and whalers new materials, techniques and incentives were introduced. Women of all three cultural groups now produce various types of artwork: the Inuvialuit (Eskimo), the Dene (Indian), and nonnative or Euro-Canadian. These cultures, along with Metis now co-exist in most Western Arctic communities, and have expressed the need to understand and cooperate with each other more fully to ensure the survival of the arts in the education of future generations.
\end{abstract}

The arts of all three heritage groups appear to have influenced each other as they developed in the Western Arctic Region over the last hundred years. Influences include historical education and church practices, changes in society and traditional ways of life, politics and government, various economic pressures including the decline of the fur industry, the rise and fall of the oil and gas industry, and the harshness of the Arctic landscape and climate. The traditional women's artwork of all three cultures is interwoven with new materiais and techniques, and must be understood within its historical context.

In the past, the production of artifacts was gender related. Women's art forms were different from those created by men, and were usually unsigned. Most women in pre-industrial societies created articles to be used by their families such as clothing, footwear, utensils, or items of household decoration. Now in a development parallel to the Arts and Crafts Movement in Europe and America, many women living in the Western Arctic also produce artwork for sale. They produce a variety of art forms that are widely acclaimed for their aesthetic value. These include Moose and Caribou-hair tufting, embroidery, beadwork, fur inlay, printmaking, painting, Delta-Braid, fur clothing, porcupine quillwork, birchbark baskets, stained glass, pottery, quilting, fashion design, and mixed media. The Western Arctic is worthy of study because each cultural group has developed unique ways of using new 
materials and techniques to reflect their collective cultural heritage, yet the influence of the other groups is observable.

Through interviews with more than fitty women who are artists, teachers, and or arts organizers, the stories of the women's artistic lives will be pieced together to show the evolving forms of Western Arctic art production. There is much to be learned from the elder women themselves about past and present practices. How the lives of producing women artists have been affected by the fabric of these interwoven cultures is part of the study of art history and aesthetics. How the women talk about their art and education is part of the study of art history, criticism, and production. Through videotape and audiotaped interviews, the voices of the women themselves will be heard as they critically discuss their art and its value in their lives, as well as historical aspects such as how they learned their skills. These tapes are the raw data around which this dissertation is being written.

\section{Statement of the Problem}

Three cultures co-exist in the Western Arctic, in varying percentages in each community. In the Mackenzie Delta region (Inuvik, Aklavik, Fort McPherson, Arctic Red River, Tuktoyaktuk, Paulatuk, and Holman), the three cultures are fairly equal in numbers, and there is striking evidence of a mutual influence in the artwork of today's women. There is also evidence of a similarity among the cultural groups in the way women's art relates to their lives. However, we know little about the women themselves, or how they value their aesthetic contributions and artistic skills. We may still be able to leam from elders about old ways that pre-date the arrival of European influence.

The indigenous peoples are struggling to maintain or revive their cultural identity, but the variety of artistic contributions to the cultural fabric of the entire region is rarely acknowledged. As land claims are settled, and new political structures emerge, affecting all sectors, this time of drastic change creates an urgent need for the cultures to understand each other. Each group has contributed an artistic, cultural, and educational heritage that is interwoven with others. All groups have expressed the need for increased knowledge and understanding of these complex interrelationships as important to future cooperation and survival.

\section{Rationale and Statement of Purpose}

The artwork produced by the women of the Western Arctic cannot be understood outside this context. Hence it is necessary to study the 
Map of Canadian Arotic Regions including Westem and Eastem Arctic

Communities of women interviewed and 'treeline' are indicated.

$\ll$ North
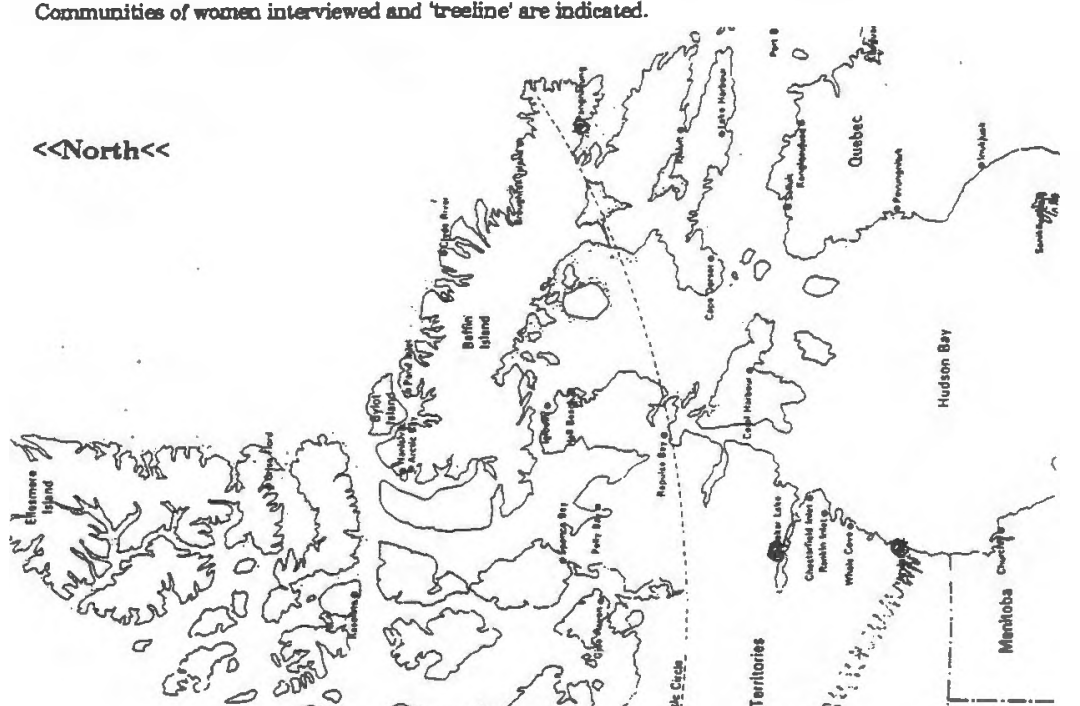

803
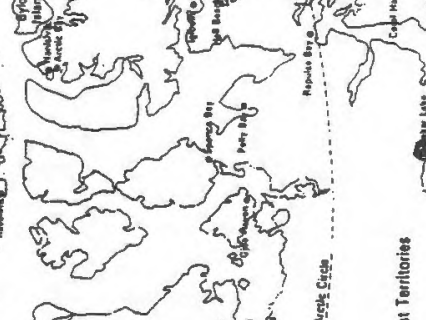
historical, social, cultural, and aesthetic milieu in which this art is created. Therefore, the purpose of this study is to discover, through conversations with women artists, and those involved in the teaching and sale of art, the context and motivation for women's artistic production. In discovering their reasons for creating art, what influences their artistic production, and how they learned their aesthetic skills, we gain insight to guide future generations. The knowledge gained through this study will enhance world understanding of how women maintain cultural identity through their art, how they benefit from cooperation with other cultures, and how they contribute to the education of future generations. This understanding has implications for curriculum in Canada's North and all of North America, and will foster more appropriate Discipline-based Art Education practices.

\section{Significance of the Study}

This study emphasizes the importance of women's art in maintaining cultural identity. It is significant not only in Canada, but in other countries of the world where indigenous peoples have been colonized by those of a dominant culture. How women in certain cultures resist assimilation and maintain cultural identity through their artwork is an important outcome of this research. Through education and passing on artistic skills to later generations, women contribute greatly to their own culture and also to the cooperation and understanding of co-existing cultural groups. The addition of this information to existing multicultural perspectives will lead to more than artistic cooperation, enabling Discipline-Based Art Education programs to better serve the various cultures of the world, and foster greater understanding among them.

\section{Methodology}

The research methods employed in this study are ethnographic. Data was collected during three summers, 1992-1994, in the Northwest Territories of Canada, mostly above the Arctic Circle. Primary sources were interviews with about thirty-five outstanding women artists. Additional primary sources were interviews with wornen who are arts organizers and teachers, more than twenty in total. All together more than fifty women were interviewed over a three year period, many more than once, and several were interviewed each year. Observations were written, and photographs were collected on each woman throughout the three years. They commented on the role of art in their lives, as well as on their growth and changes in their work. Major questions relating to the four art disciplines were asked. How did they leam their artistic skills? What are the influences on their artistic production? How do they relate to other cultural groups? How has the

Marilyn Zurmuehlen's Working Papers In Art Education 1994-1995 
educational process changed? What aesthetic value do they place on their artwork? How have they resisted cultural assimilation? How do they feel their skills can best be passed on to future generations?

The interviews were recorded on videotape and audiotape to allow the women's voices to be herd individually. The recordings also document the comments, expressions, demonstrations and stories told by the women, and assist study of these issues. Women were chosen generally on the basis of local recognition by their communities as outstanding artist, and/or through selection by their communities to participate in two festivals in Inuvik, NWT: The Great Northern Arts Festival, and the Western Arctic Crafts Festival. Additional women were interviewed in key positions related to the arts-festival organizers, store or galiery owners/managers, cultural teachers, and arts teachers. Supporting documents such as notes, letters, newspapers, comments, booklets, government publications, and archivai materials were also gathered over three years.

\section{Personal Ground of the Researcher}

After working and teaching in the arts all my life, I first visited an Arctic community in 1986 and was fascinated by the close connection between Arctic peoples and their art. In 1989 ! taught art methods at a college in the sub-Arctic for two years. The majority of my students were women from all over the arctic, and they did not think they had ever seen 'art'. As I got to know them I was interested in what their art meant to them, and how proud they were of what they made. As they got to know me and trust me they revealed very personal stories to me, and later said it was about time the women artists got the kind of recognition given male artists. I observed that when their families ran out of food, they made beautiful things to exchange with the Hudson's Bay Store for groceries. I realized that art not only played a major role in supporting their families, but it gave them a sense of pride and economic independence that was both practical and truly empowering. As I supervised student teachers in various small communities, I noticed that each place had its own style of clothing and decoration. I asked lots of questions and learned that the patterns and motifs sewn into parkas and footwear were a mark of 'home' and their community identity. In the larger communities there was wider influence, and other techniques and materials were used. i was fascinated and wanted to leam more.

I have worked for three years as Assistant Coordinator of the Great Northern Arts Festival in Inuvik, NWT, to pay expenses to do this research. This allowed close proximity to Festival and other artists, and I asked their permission for an interview outside of Festival work. I also traveled to 
communities near to Inuvik, and some southern Arctic towns, to talk to other women. My former students and the Town Councils of each community helped identify the outstanding artists I saw.

\section{Literature Review}

The literature that provides background for this study crosses many disciplines including history, Northern studies, women's studies, native education, art education, feminist theory and research, ethnographic research, anthropology, sociology, ethics, adult education, and more. I spent a year just reading and two years taking and auditing courses that covered these broad topics. These provided a sound grounding in the issues upon which I conducted the interviews. Now I begin the exciting work of analyzing the interview transcripts, and sorting through the influences on women's artwork of these three cultures in the Western Arctic.

\section{Support for the Project}

The proposal of this project was approved by the Ethics Review Committee of the University of British Columbia, and a Research License was granted all three years (1992-1994) by the Science Institute of the NWT of Canada. My housing in the arctic was graciously provided by Arctic College. Letters of support were received from the Status of Women Committee, Arctic publishers and women artists. I was privileged to have the help of former students who introduced me to key women in their communities. Arctic bookstores, and the NWT Department of Education, have offered to help publish a subsequent book on the lives and work of Western Arctic Women Artist in several indigenous languages for use in the schools. The Getty Center for Education in the Arts granted me a Doctoral Fellowship for 1994-1995 based on the merits of this project.

\section{Expected Results}

The individual faces and voices of fifty Western Arctic Women who are acknowledged as artistic and/or educational and cultural experts will begin to be heard. Their comments on traditions and artistic learning styles within their memory, and on the role of art in their lives will enrich our understanding of the educational process. How they maintain their cultural identity through their art, and relate to other cultural groups will provide perspective on the role of aesthetics in cultural relations in colonized countries. Their personal accounts and insights will contribute a collective voice to the education of future generations. Copies of the video and audiotapes will be left in the 
communities or the Yellowknife Archives for future use and study. The addition of these voices to existing multicultural perspectives will foster more than artistic understanding. It will help shape curriculum planning poiicy, and enhance the role of arts in Canada and beyond. 